\title{
Effect of pre harvest foliar spray of growth regulators on pre and post harvest parameters in ornamental sunflower genotype M-17R
}

\author{
Kirtimala B. Naik*, S. K. Nataraj, Y. G. Shadakshari, D. P. Kumar, \\ G. K. Seetharamu and K. V.Jayaprasad \\ College of Horticulture, GKVK, Campus, University of Horticultural, Sciences, Bagalkot-587104. \\ *E-mail: kirtiflori@gmail.com
}

\begin{abstract}
An experiment was conducted to study the effect of pre harvest foliar application of growth regulators on the pre and post harvest flower quality in ornamental sunflower during the year 2012-13, at College of Horticulture, GKVK campus, UHS, Bagalkot. At 60 DAS highest plant height was with GA @ 150 ppm $(154.73 \mathrm{~cm})$ followed by $\mathrm{GA}_{3} @ 200 \mathrm{ppm}(146.20 \mathrm{~cm})$ and GA @ $250 \mathrm{ppm}(145.53 \mathrm{~cm})$. Sodium silicate @ $250 \mathrm{ppm}\left(4508.77 \mathrm{~cm}^{2}\right)$ registered maximum plant spread at 60 DAS. Foliar application of GA @ $150 \mathrm{ppm}(25.00)$ produced highest number of leaves which was at par with Sodium silicate @ 250 ppm, GA $@ 200$ ppm and GA @ 250 ppm recording 24.87, 24.80 and 24.67 leaves respectively. Calcium sulphate @ 200 ppm registered highest leaf area of $\left(4930.30 \mathrm{~cm}^{2}\right)$ which was at par with Sodium silicate @ $250 \mathrm{ppm}$, Calcium sulphate@ 300 ppm, Chlormequat chloride@ 500 ppm, Sodium silicate @ 350 ppm, and Chlormequat chloride @ 1000 ppm with 4792.64, 4735.04, 4721.75, 4503.05 and $4430.02 \mathrm{~cm}^{2}$ respectively.
\end{abstract}

Key words : Ornamental sunflower, growth regulators, quality parameters, vase life

\section{INTRODUCTION}

Sunflower (Helianthus annuus L.) is native to North America and belongs to the family Compositae. The term Helianthus comes from the greek word 'Helios' meaning sun and 'anthos' meaning flower. Historically sunflower was first used as a garden plant, then as a flowering pot plant and more recently as a specialty cut flower. Specialty cut flowers can be defined as crops other than roses, carnations and chrysanthemums or other flowers that are present in the market only at a special time of the year. The type of flowers grown for the specialty cut flower market are usually field grown flowers with poor shipping characteristics. Several positive and precise results were obtained in the past by the growth regulating chemicals on various flowering annuals. Growth regulators have been found useful in overcoming the factors limiting the yield and quality of flowering annuals like marigold, china aster and daisy (Patil, 1998). The response exhibited by plants to growth regulators vary with the species, varieties and on the concentration of the chemical used. An attempt was made to study the effect of growth regulators on the pre and post harvest quality parameters of ornamental sunflonwer. The results pertaining to the effect of growth regulators on the pre and post harvest characters of ornamental sunflower genotype M-17R are discussed below.

\section{MATERIALAND METHODS}

An experiment was conducted to study the effect of pre harvest foliar application of growth regulators on the pre and post harvest flower quality in ornamental sunflower. The entire experimental area was divided into plots measuring 6.72 sq.mts each, with 4 rows of 10 plants per row. Foliar application of different chemicals on leaves was taken up three times at 15 days, 30 days and 45 days after sowing. Design followed was RCBD adopting Fisher's method of analysis of variance technique as given by Panse and Sukhatamane (2002) by using SAS package V9-3 available at statistical cell, IIHR with three replications and sixteen treatments. 


\section{Treatments:}

$\mathrm{T}_{1}$ : Gibberellic acid (GA) @ $150 \mathrm{ppm}$

$\mathrm{T}_{10}$ : Calcium sulphate $\left(\mathrm{CaSo}_{4}\right) @ 200 \mathrm{ppm}$

$\mathrm{T}_{2}$ : Gibberellic acid $\left(\mathrm{GA}_{3}\right) @ 200 \mathrm{ppm}$

$\mathrm{T}_{11}$ : Calcium sulphate $\left(\mathrm{CaSo}_{4}\right) @ 300 \mathrm{ppm}$

$\mathrm{T}_{3}$ : Gibberellic acid $\left(\mathrm{GA}_{3}\right) @ 250 \mathrm{ppm}$

$\mathrm{T}_{12}$ : Calcium sulphate $\left(\mathrm{CaSo}_{4}\right) @ 400 \mathrm{ppm}$

$\mathrm{T}_{4}$ : Benzyl adenine (BA) @ 400 ppm

$\mathrm{T}_{13}$ : Chlormequat chloride (CCC) @ 500 ppm

$\mathrm{T}_{5}$ : Benzyl adenine (BA) @ 500 ppm

$\mathrm{T}_{14}$ : Chlormequat chloride (CCC) @ 1000 ppm

$\mathrm{T}_{6}$ : Benzyl adenine (BA) @ $600 \mathrm{ppm}$

$\mathrm{T}_{15}$ : Chlormequat chloride (CCC) @ 1500 ppm

$\mathrm{T}_{7}$ : Sodium silicate $\left(\mathrm{NaSiO}_{3}\right) @ 250 \mathrm{ppm}$

$\mathrm{T}_{16}$ : Control (No spray)

$\mathrm{T}_{8}$ : Sodium silicate $\left(\mathrm{NaSiO}_{3}\right) @ 350 \mathrm{ppm}$

$\mathrm{T}_{9}$ : Sodium silicate $\left(\mathrm{NaSiO}_{3}\right) @ 450 \mathrm{ppm}$

\section{RESULTS AND DISCUSSION}

\section{Vegetative parameters}

At 60 DAS highest plant height was with $\mathrm{GA}_{3}$ @ 150 ppm $(154.73 \mathrm{~cm})$ followed by GA @ 200 ppm $(146.20 \mathrm{~cm})$ and $\mathrm{GA}_{3} @ 250 \mathrm{ppm}(145.53 \mathrm{~cm})$. While it was minimum with $\mathrm{T}_{15}$ Chlormequat chloride @ 1500 ppm $(105 \mathrm{~cm})$ and $\mathrm{T}_{10}$ Calcium sulphate @ 200 ppm $(106.33 \mathrm{~cm})$. It may be because though growth is under genetic control, environmental factors also influence it simultaneously. Hence, application of growth regulators play significant role in modifying growth of plants. Similar result with regard to $\mathrm{GA}_{3}$ to promote maximum plant height was reported by Syamal et al. (1990) Leshem (1992); Herrera and Benedetto (1992), Dutta et al. (1993); Kamenidou (2005), Spitzer et al. (2011) and Dorajirao (2010).Sodium silicate @ 250 ppm (4508.77 cm²) registered maximum plant spread at $60 \mathrm{DAS}$, followed by Chlormequat chloride @ 500 ppm (4209.49 $\mathrm{cm}^{2}$ ). Silicon spray was earlier reported by Wroblewska and Debicz (2011) to increase plant spread in ornamental plants by stimulating synthates. Foliar application of $\mathrm{GA}_{3} @ 150$ ppm (25.00) produced highest number of leaves which was at par with Sodium silicate @ 250 ppm, GA 3200 ppm and GA 3
@ 250 ppm recording 24.87, 24.80 and 24.67 leaves respectively. Calcium sulphate @ 200 ppm registered highest leaf area of $\left(4930.30 \mathrm{~cm}^{2}\right)$ which was at par with Sodium silicate @ 250 ppm, Calcium sulphate @ 300 ppm, Chlormequat chloride @ 500 ppm, Sodium silicate @ 350 ppm, and Chlormequat chloride @ 1000 ppm with 4792.64, 4735.04, 4721.75, 4503.05 and $4430.02 \mathrm{~cm}^{2}$ respectively. The activity of sodium silicate may be attributed to its ability to reinforce cell wall and maintaining water status in plants and adequate supply of nutrients as reported by Wroblewska and Debicz (2011). Positive activity of calcium sulphate for growth was also reported by Parmeshwar (2010) in sunflower. Chlormequat chloride is reported to enhance availability of carbohydrates during growth and development of plant. Lokhande et al. (2008); Kamenidou et al. (2008) also reported that depending on the source and concentration of silicon supplied, several horticultural traits were improved in greenhouse produced sunflower (Table 1).

\section{Flower quality parameters}

Foliar application of Gibberellic acid $\left(\mathrm{GA}_{3}\right) @$ $150 \mathrm{ppm}$ favoured longest flower stalk length (35.93 cm) followed by GA $@ 200$ ppm $(35.53 \mathrm{~cm})$. Increase in stalk length may be due to increase in cell division and cell elongation. Similar results were reported by Kore et al. (2003) with GA @ 200 ppm in china aster and Parmeshwar (2010) with GA @ 150 ppm in sunflower. Increased flower stalk girth was observed with the foliar application of Chlormequat chloride @ $1500 \mathrm{ppm}$ recording $0.46 \mathrm{~cm}$ which was at par with Sodium silicate @ 250 ppm and Calcium sulphate @ $200 \mathrm{ppm}$ (0.44 and $0.43 \mathrm{~cm}$ respectively). It might be attributed to the increase in photosynthetic activity and accumulation of more carbohydrates in the flower stalk and enhanced varietal response to application of certain growth regulators. Similar results with relation to silicate application were earlier reported by Chikkur (2010) in rose and Kameniduo et al. (2010) by $\mathrm{NaSiO}_{3}$ foliar spray in sunflower (Table 2).

Sodium silicate@250 ppm significantly increased the flower head diameter $(11.37 \mathrm{~cm})$ and was at par with Chlormequat chloride @ 1500 ppm, Calcium sulphate@300ppm, Chlormequat chloride @ 1000 ppm and Sodium silicate @ 450 ppm recording $11.27,11.18,11.11$ and $11.06 \mathrm{~cm}$ respectively. Smallest flower head diameter was observed with the foliar application of GA $@ 200$ ppm (6.96 cm) and GA $@$ 


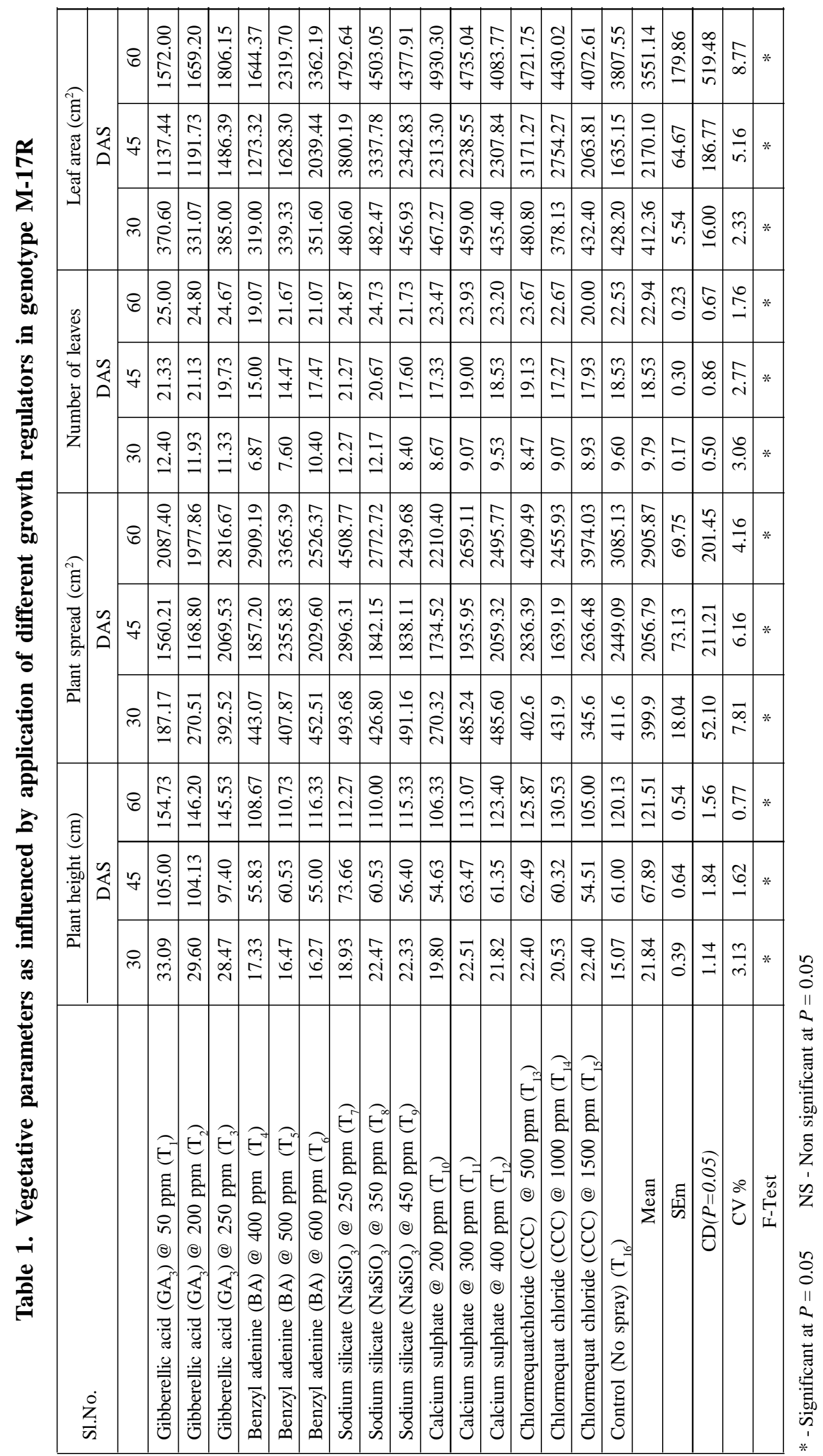


$150 \mathrm{ppm}(7.19 \mathrm{~cm})$. Flower disc diameter increased with the foliar application of Chlormequat chloride @ 1500ppm (4.47) which was at par with Chlormequat chloride@1000ppm, Sodium silicate@ 250 ppm and Calcium sulphate @ 200 ppm recording 4.32, 4.11 and $4.00 \mathrm{~cm}$ respectively. Smallest flower disc diameter was produced with the foliar application of $\mathrm{GA}_{3} @$ 250 ppm and $\mathrm{GA}_{3} @ 150$ ppm $(1.80$ and $1.89 \mathrm{~cm}$ respectively). Flower head diameter in sunflower ranging from $8-15 \mathrm{~cm}$ is considered ideal for florist according to Sloan and Harkness (2006). With the application of growth regulators there is a decrease in apical dominance leading to the development of side buds by diverting carbohydrates for flower development. Similar results were reported by Lokhande et al. (2008), Muhammad et al. (1997), Katkar et al. (2003) and Kamenidou (2005) by application of various growth regulators (Table 2).

Total number of flower heads per plant was highest with the foliar application of Sodium silicate @ 250 ppm (24.93) followed by Sodium silicate @ 350 ppm, Chlormequat chloride@ 1500 ppm and Chlormequat chloride @ 1000 ppm (22.53,22.40 and 22.13).

Foliar spray of Sodium silicate @ 250 ppm (20.80) followed by Sodium silicate @ 350 ppm (19.67) produced more number of marketable flower heads per plant. Total number of marketable flowers per hectare increased with the foliar application of Sodium silicate @ 250 ppm (11.55) lakh flowers ha ${ }^{-1}$ followed by Sodium silicate @ 350 ppm (10.93) lakh flowers $\mathrm{ha}^{-1}$. It may be because sodium silicate application increased the parameters such as stalk girth, flower diameter and number of petals per flower. Similar results with application of silicon were reported by Chikkur, 2010 in rose (Table 2).

While, post harvest cumulative water uptake was highest in the flowers harvested from plants with foliar application of Sodium silicate @ 250 ppm, BA @ 600 ppm and $\mathrm{GA}_{3} @ 150$ ppm recording 40.80, 39.20 and 38.23 g respectively. Cumulative water loss was induced in the flowers harvested from plants with foliar application of $\mathrm{GA}_{3} @ 250$ ppm (42.63 g) followed by Sodium silicate @ 450ppm, GA 3 150ppm and Calcium sulphate @ 200 ppm recording 41.40, 41.23 and 40.27 $\mathrm{g}$ respectively. While lowest cumulative water loss was observed with foliar application of BA @ 400 ppm and Chlormequat chloride @ 1000 ppm recording 34.03 and $34.43 \mathrm{~g}$ respectively. Similar results with application of $\mathrm{GA}_{3}$ were reported by Michalczuk et al. (1989) and Torre et al. (1999) in rose and Parmeshwar (2010) in sunflower (Table 2).

Sodium silicate @ 250 ppm increased the post harvest vase life of cut flowers (5.90) and was at par with Sodium silicate @350 ppm, Chlormequat chloride @ 1500ppm and Chlormequat chloride @ 1000 ppm recording 5.70, 5.67 and 5.53 days respectively. Vase life was enhanced by 2.10 days in comparison to control. This may be because of the contribution of Sodium silicate and with respect to pre harvest floral parameters which in turn contributed to maximize post harvest vase life of the cut flowers. Similar results were also reported by Srikanth (2011) in china aster and Parmeshwar (2010) in sunflower (Table 2). 


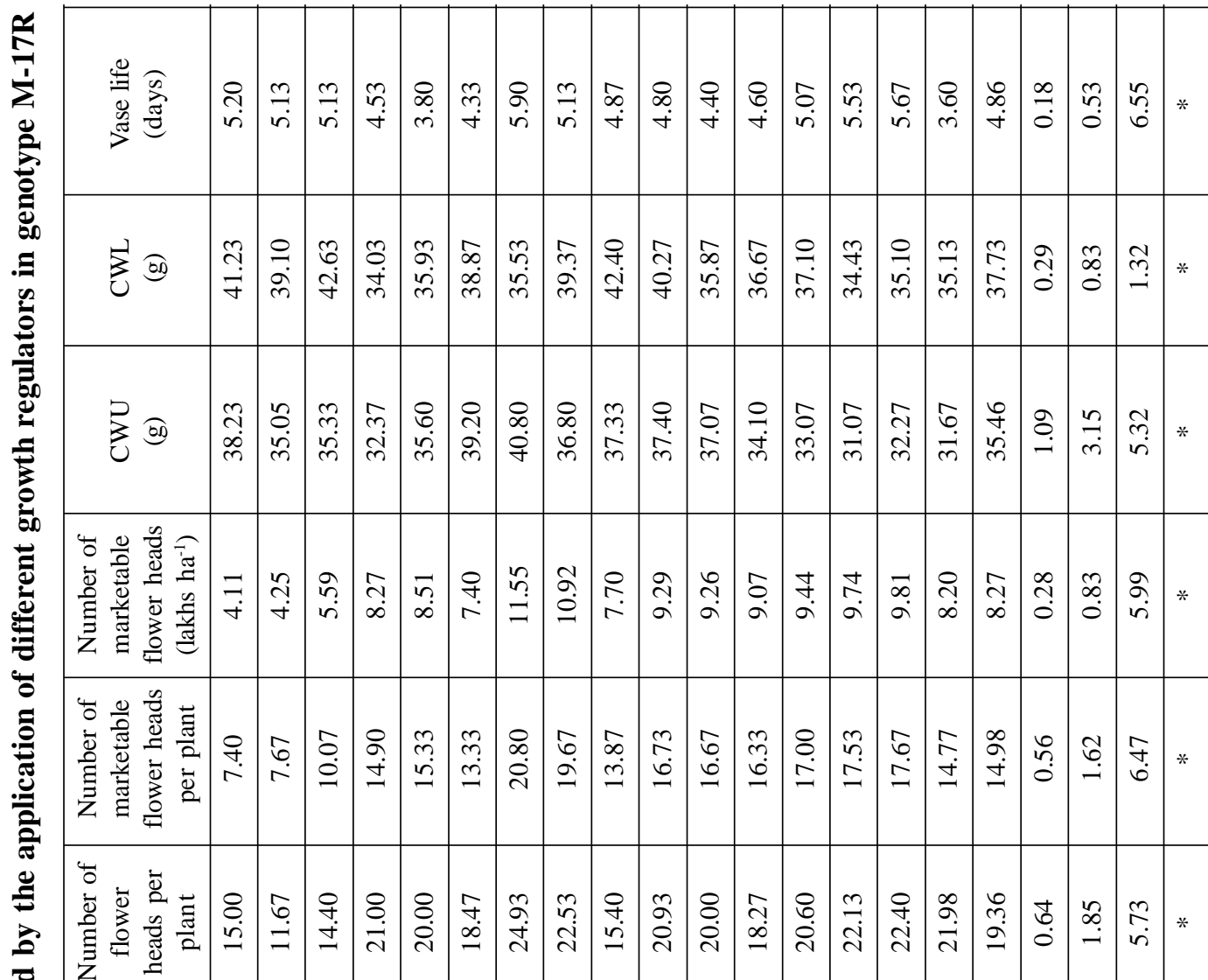

递

冚

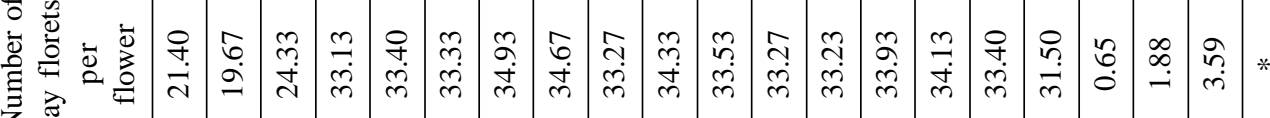

:

范

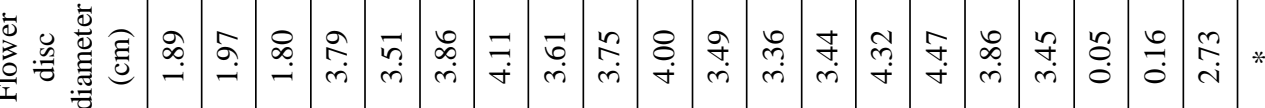

总 莺 离

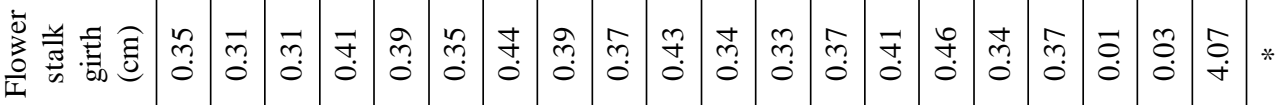

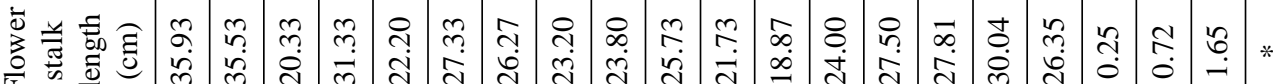

ก

$\frac{0}{\frac{0}{0}}$

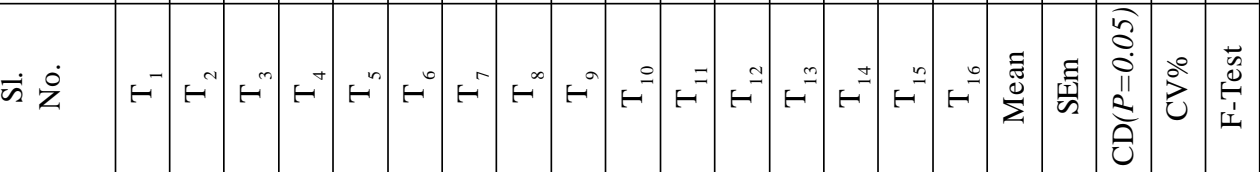

ถิํํำ

\&̊으

(8) (8)

记

용

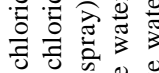

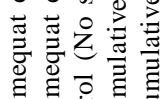

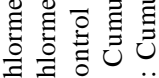

ฮี ठठ 究

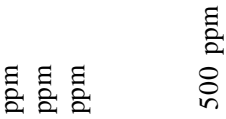

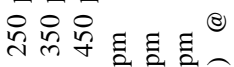
(8) \&) \&

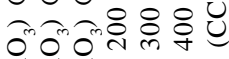

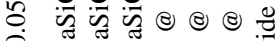
乙艺艺品

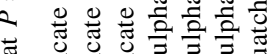

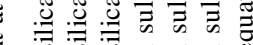
产

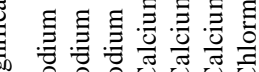
a in in ........

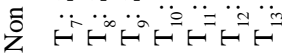
z

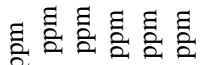

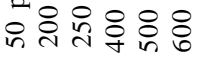
(8) (8) (8) (8) (8) (8)

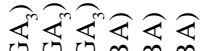

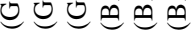

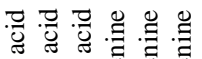

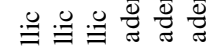
.

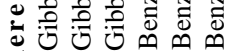




\section{REFERENCES}

Chikkur, S. S., 2010, Silicon as foliar spray on growth, yield and quality of Rose. M.Sc. Thesis, Univ. Agri. Sci. Bengaluru.

Dorajirao, A. V. D., Mokashi, A. N., Patil, V. S., Venugopal, C. K., Lingaraju, S. and Koti, R. V., 2010, Effect of plant spacing on growth, yield and benefit-cost ratio in garland chrysanthemum (Chrysanthemum coronarium L.). J. Asian Hort., 6 (3): 87-93.

Dutta, J. P., Ramadas, S.and Khadar, M. D., 1993 Regulation of flowering by growth regulators in chrysanthemum (chrysanthemum indicum. Linn.) Cv. Co1. S. I nd.Hort., 41 (5): 293-299.

Herrera, O. J. And Benedetto, A. H., 1992, New growth retardant uniconazole for cut chrysanthemums. Rev. Fac. Agron., 13 (2-3): 137-143.

Kamenidou, S., 2005, Silicon supplementation affects greenhouse produced cut flowers. M.Sc. Thesis. Oklahoma State University. Stillwater, Oklahoma.

Kameniduo, S. And Todd, J. C. And Stephen, M., 2008, Silicon supplements affect floriculture quality traits and elemental nutrient concentrations of greenhouse produced gerbera. Scien. Hort., 123: 390-394.

Katkar, P. B., Naik, D. M., Boodamwad, S. G. and Gharat, S. N., 2003, Influence of plant growth regulators on flowering, quality and yield of flower in china aster cv. California giant mix. $S$. Ind. Hort., 53(1-6): 378-381.

Kore, V. N., Meman, S. L. and Burondkar, M. M., 2003, Effect of GA3 and fertigation on flower quality and yield of China aster (Callistephus chinensis L.) var. "Ostrich Plume Mixed" under Konkan agro-climatic conditions. The Orissa J. of Hort. 31(1): 58-60.

Lokhande, B. S., Deshmukh, M. and Kawarkhe, V. J., 2008, Effect of growth regulators on growth and flower yield of annual chrysanthemum. Ann. Plt. Phsio., 22 (2): 268-271.
Leshem, Y. Y. 1992, Plant Membrane: A Biophysical Approach to Structure, Development and Senescence. Kluwer Academic Publisher, Dordrecht. ISBN 0-7923-1353-4.

Michalczuk, B., Goszczynska, R. D., Rudnicki, D. and Halevy, A. H., 1989, Calcium promotes longevity and bud opening in cut rose flowers. Israel $J$. Bot., 38: 209-215.

Muhammad A., Sharafat, K., Shah, A. H. and Khalil, S. A., 1997, Response of large flowered incurve chrysanthemum (Chrysanthemum morifolium) to various concentrations of paclobutrazol. Sarhad J. Agri., 13(2): 117-122.

Panse, V.S and Sukhatamane, P.V., 2002, Statistical methods for Agriculture workers, ICAR, New Delhi, pp: 152- 155.

Parmeshwar, A. S., 2010, Evaluation of sunflower (Helianthus annuus L.) germplasm for ornamental cut flower production. MSc. Thesis Univ. Agri. Sci., Bengaluru.

Patil, V. S., 1998, Standardization of production technology in daisy (Aster amellus L.).

Ph.D. Thesis. Univ. of Agric. Sci., Dharwad.

Syamal, M., Rajput, C. B. S., Upadhyay, R. K. and Singh, J. N., 1990, Effect of $\mathrm{GA}_{3}$ and $\mathrm{MH}$ on growth, flowering and seed yield of Marigold and China aster. Indian J. Hort., 47 (4): 439441.

Spitzer, T., Matusinsky, P., Klemova, Z. and Kazda, J., 2011, Management of sunflower stand height using growth regulators. Plant soil environ. 57(8): 357-363.

Srikanth, L. G., 2011, Influence of growth regulators on growth, flowering and yield of china aster (Callistephus chinensis L. Nees). M.Sc. Thesis, Univ. Agri. Sci. Bengaluru.

Torre, S., Borochov, A. and Halevy, A. H., 1999, Calcium regulation of senescence in rose petals. Physiol. Plant., 107: 214-219.

Wroblewska, K. and Debicz, R., 2011, The effect of silicon application on the development of season ornamental plants. Acta Agrobotanica, 64 (4): 107-114. 